Int. J. Agril. Res. Innov. Tech. 10(2): 164-169, December 2020 Available online at https://ijarit.webs.com DOI: https://doi.org/10.3329/ijarit.v10i2.51590

https://www.banglajol.info/index.php/IJARIT

\title{
Mitigation of land scarcity situation through tenure practices: a study on two selected villages in Jashore district of Bangladesh
}

\author{
A.K. Ghosh* and M.H.K. Sujan \\ Received 31 October 2020, Revised 16 December 2020, Accepted 24 December 2020, Published online 31 December 2020
}

\begin{abstract}
A B S T R A C T
Bangladesh is one of the most densely populated countries with immense pressure on agricultural land in rural areas. Mainstream of the rural households depend on either agriculture or its associated activities for their livelihood. However, rural land distribution is highly skewed, majority of them are landless. Under such a land scarce situation, farmers in rural areas have been gradually inclining towards land tenancy. Present study steered to explore the nature and volume of temporary land transaction through tenancy agreement in studied areas and to scrutinize its role in aligning land distribution. In 2017, a total of 166 farmers were randomly selected from two different villages in Jashore district for study. Result of the study administrated that land tenancy practice has been significantly mitigating land disparity among rural farmers. Study also explored that comparatively rich farmers are leaning towards tenant out land and most of these lands tenanted in by the landless and marginal farmers. Consequently, on an average landless farm could significantly increases their cultivable land from 0.01 acre to 0.98 acre compared to the marginal farm 0.31 to 0.73 acres. At the same time, cultivable land of medium farm has decreased as of 3.74 acres to 2.83 acres in studied villages.
\end{abstract}

Keywords: Land lease, Land scarcity, Landless, Mortgage, Tenancy.

Dept. of Development and Poverty Studies, Sher-e-Bangla Agricultural University, Dhaka, Bangladesh.

*Corresponding author’s email: ashoke1971@yahoo.com (A.K. Ghosh)

Cite this article as: Ghosh, A.K. and Sujan, M.H.K. 2020. Mitigation of land scarcity situation through tenure practices: a study on two selected villages in Jashore district of Bangladesh. Int. J. Agril. Res. Innov. Tech. 10(2): 164-169. https://doi.org/10.3329/ijarit.v10i2.51590

\section{Introduction}

Bangladesh is an agrarian country and land is considered as a very precious asset among the rural farm households. However, land distribution is very uneven and as a result major share of cultivable land owned by very few people. On the other hand, mainstream of the rural households are either landless or near landless (Raihan et al., 2009). A key factor of rural poverty is landlessness and limited access to cultivable land. The extent of landlessness is very high in South Asian countries like 22.0\% in India and 49.6\% in Bangladesh (Kabir et al., 2014, Rashid, 2015). Landlessness often materializes the manifestation of poverty, datedness and powerlessness of the majority of rural households. This situation has been worsening gradually because of abnormal population pressure, dearth of land, low productivity in agriculture, split of family, river erosion and alteration of cultivable land in different purposes (Rahman and Manprasert, 2006; Rana et al., 2019). Under such a situation, land poor farmers find tenancy as an alternative and viable option to continue cultivation as well as utilize their spare family labor. Earlier studies also showed increasing trend of rented in land to the total cultivable land. The amount of rented in land was only $23.4 \%$ in 1988 which has increased to $32.8 \%$ in $2000,39.8 \%$ in 2008 , and $47.5 \%$ in 2014 (Sen, 2018). Generally, land tenancy refers to the temporary possession or occupancy of land that belongs to other persons. In that cases, owners allow tenant to use their land for a certain period of time for which owner receive some fixed amount of cash, goods or services. Nature of land tenancy practices varies from time to time and place to place. Studies show that more than onesixth of the total cultivated lands in Bangladesh are operated under different tenurial arrangements (Griffin et al., 2002; Taslim and Ahmed, 1992). Three major types of land tenure practices are very common in rural Bangladesh such as; land lease, sharecropping and mortgage. Land lease refers to utilization of land by the tenant who pays fixed amount of rent for certain duration. In case of sharecropping agreement, 
tenant utilize land in return of paying certain portion of output produced from that land. Mortgage agreement accomplished when tenant keep a significant amount of money to the owner and utilize their land until they paid back the given amount.

Considering the importance of land tenancy, several studies have conducted on land tenure and its associated poverty related issues. Haque and Jinan (2017) conducted a study to examine the impact of land tenure system on socioeconomic characteristics of the farmers in Mymensingh district. They found a positive relationship between tenure categories and annual incomes of the farmers. Islam and Maharjan (2015) conducted a study in two upazilas under Comilla and Tangail districts, Bangladesh and found that the technical efficiency of the farmers were varied among different farm categories. Their study also revealed that land rent had significant positive impact on the technical efficiency of the farmers. Nasrin and Uddin (2011) conducted a study in two villages under Sadar upazila of Mymensingh district to measure relative efficiency of farming under tenancy systems. They found that cash tenants earned more profit than share tenants from Boro rice production. All the above mentioned studies have addressed abundant issues regarding landlessness, land tenure practices, its forms and effects on profitability and productivity. Still ample of issues in micro level have not yet explored. Present study is an endeavor to grasp such issues; as to reconnaissance the nature of tenure practices, volume of land transacted not only among diverse classes of farmers but also in the locality. This study also investigated the contribution of existing tenancy practices to mitigate the severe land scarcity among landless and marginal farmers.

\section{Methodology}

\section{Date sources}

Primary data was collected from two adjacent villages namely, Lebutala and Kodalia under Sadar upazila of Jashore district, Bangladesh. A list of farm households was collected with the assistance of local Union Parshad. A total of 166 households were randomly selected for discussion and necessary data collection. Sample includes all type of farmers; tenant, land owner and non-tenant. Non-tenant farmers were also included (as it was random sample) to have holistic evidences regarding tenancy and its gravity in these localities. Such approach was commenced to validate certain vibrant answers like, percentages of farmers and land under tenancy in these villages. Data regarding characteristics of the respondent, land ownership, land tenancy, its associated information and problems were collected using pre-tested interview schedule during May to June, 2017. Besides, focus group discussion (FGD) and participatory rural appraisal (PRA) were conducted with local leaders and neighboring people to assess the status of land tenure practices in the study areas and to cross check the collected data.

\section{Analytical technique}

Collected data were analyzed by using descriptive statistics to attain the objectives of this study and to obtain meaningful results. Various descriptive statistical measures like sum, average, percentages, etc. were used in tabular form to ascertain the objectives.

\section{Results and Discussion}

\section{Land holding sizes among different farm categories}

The scarcity of cultivable land has been increasing day by day due to the rapid population growth in Bangladesh. Consequently, land holding size is getting small to smaller and finally this process leads to the landlessness. Table 1 shows different categories of farmers on the basis of their owned cultivable land. Result shows that 9.04\% farmers were landless with very tiny amount of land (up to 0.04 acre of land). Besides, a significant portion $(22.29 \%)$ of the farmers were on marginal farm (with 0.05-0.49 acre) category. Result also shows that 55.42 and $13.25 \%$ of the respondents were on small (with $0.50-2.49$ acre) and medium farmer (with 2.507.49 acre) category, respectively.

Table 1. Different farm categories with their average sizes of cultivable land.

\begin{tabular}{|l|c|c|c|}
\hline Farms categories & No. of H.H. & (\%) of H.H. & Average farm size (in acre) \\
\hline Landless & 15 & 9.04 & 0.01 \\
\hline Marginal & 37 & 22.29 & 0.31 \\
\hline Small & 92 & 55.42 & 1.15 \\
\hline Medium & 22 & 13.25 & 3.74 \\
\hline All farms & 166 & 100.00 & 1.20 \\
\hline
\end{tabular}

Note:

1. H.H. refers Household

2. Landless farm indicates land up to 0.04. Marginal farm is with 0.05 -0.49 acres of land, small farm is with $0.50-2.49$ acres of land, medium farm is with 2.50-7.49 acres and large farm with 7.50 acres of land and above. 
Moreover, same table shows that the average farm size of the landless and marginal farmers were only 0.01 and 0.31 acres, respectively. It was also found that the small farmers were enjoying on an average about 1.15 acres of land compared to 3.74 acres by the medium farmer.

This implies that land scarcity existed in rural Bangladesh and it is unevenly distributed; half of them having very tiny piece of land or without land. On the other hand, upper one-fifth of the farmers having handsome amount of cultivable land.

\section{Farm categories and land tenure practices}

Findings of the study show that almost all of the poor farmers (landless and marginal) were engaged with land tenancy activities (Table 2).
The reason behind this behavior was to secure their household food requirement by using unemployed family labor. On the other hand, upper part of the well-off farmers was tenanted out their land. Results reveal that a higher percentage (93.33\%) of landless farmers was tenanted in and $91.89 \%$ of the marginal farmers were also engaged in similar practices. Additionally, a less percentage $(13.51 \%)$ of the marginal farmers was tenanted out their land. It was also found that $31.52 \%$ of the small farmers tenanted in land against $25.00 \%$ of them were tenanted out. In case of medium farm, only 9.09\% cases were found as tenanted in and $45.45 \%$ as tenanted out their land. Findings of this study also depict that on an average $47.59 \%$ of the farmers among all categories tenanted in and $22.89 \%$ were tenanted out their land.

Table 2. Different farm categories with their engagement in tenure practices.

\begin{tabular}{|l|c|c|c|c|c|}
\hline \multirow{2}{*}{ Farm categories } & Total No. of & \multicolumn{3}{|c}{ Tenant in land } & \multicolumn{2}{c|}{ Tenant out land } \\
& H.H. & No. of H.H. & \% of H.H. & No. of H.H. & $\%$ of H.H. \\
\hline Landless & 15 & 14 & 93.33 & O & 0.0O \\
\hline Marginal & 37 & 34 & 91.89 & 5 & 13.51 \\
\hline Small & 92 & 29 & 31.52 & 23 & 25.00 \\
\hline Medium & 22 & 2 & 9.09 & 10 & 45.45 \\
\hline All farms & 166 & 79 & 47.59 & 38 & 22.89 \\
\hline
\end{tabular}

\section{Types of tenancy and land transaction}

Different types of tenancy practices observed in studied villages. Result comes out as landless and marginal farmers greatly absorb tenanted in land through mortgage, sharecropping and leasing agreements. Results also express that about $33.33 \%, 20.00 \%$ and $40.00 \%$ of the landless framers leased, sharecropped and mortgaged in land, respectively (Table 3 ). The incidence of mortgage in land is comparatively higher for its secured and durable nature of agreement. It is worth to mention that none of the landless farmers were found tenanted out their land. Result also reveals that $21.62 \%$ of the marginal farmers leased in land followed by $35.14 \%$ sharecropped and $32.43 \%$ mortgaged in land, respectively. Again, a few $8.11 \%, 2.70 \%$ and
$2.70 \%$ of the marginal farms were engaged in leased, sharecropped and mortgaged out their land, respectively. Among the small farmers, $10.87 \%$ were leased in against only $1.09 \%$ leased out of their land. In case of sharecropping, 9.78\% and $8.70 \%$ of the small farms sharecropped in and out, respectively. Again $10.87 \%$ and $15.22 \%$ of the small farmers were found mortgaged in and out of their land, respectively. None of the medium farmers were found leased in land except $13.64 \%$ of them were found leased out. Only $9.09 \%$ of the medium farms were sharecropped in land against $27.27 \%$ of sharecropped out. None of the medium farmers was mortgaged in land except few (4.55\%) mortgaged out their land.

Table 3. Farm categories under different tenure practices.

\begin{tabular}{|c|c|c|c|c|}
\hline \multirow[t]{2}{*}{ Types of land tenancy } & \multicolumn{4}{|c|}{ Farm categories } \\
\hline & Landless & Marginal & Small & Medium \\
\hline Incidence of leasing & 33.33 & 29.73 & 11.96 & 13.64 \\
\hline Lease in H.H. & 33.33 & 21.62 & 10.87 & 0.00 \\
\hline Lease out H.H. & 0.00 & 8.11 & 1.09 & 13.64 \\
\hline Incidence sharecropping & 20.00 & 37.84 & 18.48 & 36.36 \\
\hline Sharecropping in H.H. & 20.00 & 35.14 & 9.78 & 9.09 \\
\hline Sharecropping out H.H. & 0.00 & 2.70 & 8.70 & 27.27 \\
\hline Incidence of mortgage & 40.00 & 35.13 & 26.09 & 4.55 \\
\hline Mortgage in H.H. & 40.00 & 32.43 & 10.87 & 0.00 \\
\hline Mortgage out H.H. & 0.00 & 2.70 & 15.22 & 4.55 \\
\hline
\end{tabular}


Result suggests that landless and marginal farmers are mostly tenanted in land; through leasing, sharecropping and mortgaging. All this land came from medium and small farmers as they have enough land and sometimes felt labor shortage in family. However, many of the small farmers were found tenanted in land as they were capable of handling much land with their family labors. Table 4 represents quantity of land transected among different categories of farmers. It is evident that landless farmers were received $5.10,2.31$ and 7.09 acres of cultivable land through leasing, sharecropping and mortgaging in land, respectively. They did not lease, sharecrop and mortgage out any land. On the other hand, marginal farmers were leased in 3.11, sharecropped in 7.47 and mortgaged in 6.20 acres of land against very little $0.81,0.33$ and 0.35 acres of land out through leased, sharecropped, and mortgaged. Result also denotes that small farmers acquired 5.84, 5.89 and 7.38 acres of land through leased, sharecropped and mortgaged in land, respectively. On the other hand, $0.66,6.22$ and 7.96 acres of land were transferred out through leased, sharecropped and mortgaged, respectively. Very little amount of land (2.32 acres) was found as sharecropped in among the medium farmers against 4.54, 17.33 and 0.66 acres of land out through leased, sharecropped and mortgaged, respectively.

Table 4. Farm categories and quantities of land transaction through different tenure practices.

\begin{tabular}{|l|c|c|c|c|}
\hline \multirow{2}{*}{ Types of land tenancy } & Farm categories and quantity of lad under tenancy (in acre) \\
\hline Land under leasing & Landless & Marginal & Small & Medium \\
\hline Lease in land & 5.10 & 3.92 & 6.50 & 4.54 \\
\hline Lease out & 5.10 & 3.11 & 5.84 & 0.00 \\
\hline Land udder sharecropping & 0.00 & 0.81 & 0.66 & 4.54 \\
\hline Sharecropping in land & 2.31 & 7.80 & 12.11 & 20.65 \\
\hline Sharecropping out land & 2.31 & 7.47 & 5.89 & 2.32 \\
\hline Land under mortgage & 0.00 & 0.33 & 6.22 & 17.33 \\
\hline Mortgage in land & 7.09 & 6.55 & 15.34 & 0.66 \\
\hline Mortgage out land & 7.09 & 6.20 & 7.38 & 0.00 \\
\hline
\end{tabular}

Changes in land holding sizes among farm categories

Result of the study straightly indicates that medium farmers tenanted out more than onefourth of their land which was tenanted in by landless and marginal farmers (Table 5 ). This has increased cultivable landholding among poorer section of the farmers. Result of the study demonstrates that all together landless farmers owned 0.11 acres of land which was only $0.06 \%$ of the total cultivated land. On the other hand, marginal farmers possessed 11.56 acres of land and that was $5.78 \%$ of total land. However, small and medium farmers owned as much as $\mathbf{1 0 5 . 8 4}$ and 82.36 acres of land constituting about $52.95 \%$ and $41.21 \%$ of the total land, respectively. Same table also shows that landless farmers gained a significant portion (7.25\%) of the land through tenancy. Similarly, marginal farmers also tenanted in $8.40 \%$ of land with $0.75 \%$ tenanted out. Moreover, small and medium farmers received $9.56 \%$ and $1.16 \%$ of land in compared to $7.42 \%$ and $11.27 \%$ of land out. Overall findings of the study reveal that out of 199.87 acres of total land, a significant portion was (26.37\%) tenanted in and tenanted (19.44\%) out.

Table 5. Farm categories, quantity of land holding and percentage of total land tenant in and out.

\begin{tabular}{|c|c|c|c|c|c|}
\hline $\begin{array}{l}\text { Farm } \\
\text { category }\end{array}$ & $\begin{array}{l}\text { Number of } \\
\text { households }\end{array}$ & $\begin{array}{l}\text { Land holding } \\
\text { (in Acre) }\end{array}$ & $\%$ of total land & $\begin{array}{l}\% \text { of land } \\
\text { tenant in }\end{array}$ & $\begin{array}{l}\% \text { of land } \\
\text { tenant out }\end{array}$ \\
\hline Landless & 15 & 0.11 & 0.06 & 7.25 & 0.00 \\
\hline Marginal & 37 & 11.56 & 5.78 & 8.40 & 0.75 \\
\hline Small & 92 & 105.84 & 52.95 & 9.56 & $7 \cdot 42$ \\
\hline Medium & 22 & 82.36 & 41.21 & 1.16 & 11.27 \\
\hline All farms & 166 & 199.87 & 100.00 & 26.37 & 19.44 \\
\hline
\end{tabular}

Result straightly shows that all farm sizes moderated through land transaction among different categories of farmers. Farmers from poorer section received substantial amount of land compared to the land rich farmers. Consequently, cultivable landholding sizes of poor farmers increased significantly. This process itself reduces the land size of medium farmers. This was transpired as because tenancy practices acted as a catalyst to mitigate uneven land distribution problems. Table 6 reveals that change in possession of cultivable land after engaging with tenancy practices. It is found that tenancy practices lead to increase the 
landholding size significantly from 0.11 to 14.63 acres for all landless farmers while 0.01 to 0.98 acres per household. Similarly, total land possession of all marginal farmers have increased from 11.56 to 26.85 acres with an increment of 0.31 to 0.73 acres of land per household. However, very little change in land possession was observed among small farmers as their total land holding increased from 105.84 to 110.10 acres with per household 1.15 to 1.20 acres. Moreover, the land possession situation has decreased significantly 82.36 to 62.15 acres for all medium farmers and 3.74 to 2.83 acres per household.

Table 6. Possession of cultivable land before and after tenancy agreement.

\begin{tabular}{|l|c|c|c|c|}
\hline \multirow{2}{*}{ Farm category } & \multicolumn{2}{c}{ Total cultivable land owned (acre) } & \multicolumn{3}{c|}{ Cultivable land under tenancy (acre) } \\
\cline { 2 - 5 } & Total land & Land per H.H. & Total land & Land per H.H. \\
\hline Landless & 0.11 & 0.01 & 14.63 & 0.98 \\
\hline Marginal & 11.56 & 0.31 & 26.85 & 0.73 \\
\hline Small & 105.84 & 1.15 & 110.10 & 1.20 \\
\hline Medium & 82.36 & 3.74 & 62.15 & 2.83 \\
\hline
\end{tabular}

\section{Problems encountered by tenant farmers}

Although tenancy practices have been playing an important role to redistribute the cultivable land temporarily but still some problems are faced by the farmers. Table 7 exhibits that poorer section of the farmers mainly faced the problem of shortage of capital (57.14\%), higher payment for land (21.43\%) and competitive land tenancy market (21.43\%). Similarly, among the marginal farmers, $38.24 \%$ mentioned lack of capital, $35.29 \%$ mentioned higher rent for land and
$20.59 \%$ found competition in tenancy market. However, small farmers faced problem differently as $31.03 \%$ found shortage of capital, $10.34 \%$ found uncertainty in tenancy market, $17.24 \%$ worried about the absence of legal contract, $24.14 \%$ found higher rent and $17.24 \%$ did not find any problems. Medium farmers were always privileged as $50 \%$ of them found problem as land tenancy market operated through verbal contract and another 50\% did not find any problems.

Table 7. Nature of the problems encountered by different categories of farmers under tenancy.

\begin{tabular}{|l|c|c|c|c|}
\hline \multirow{2}{*}{$\begin{array}{l}\text { Nature of the } \\
\text { problems }\end{array}$} & \multicolumn{3}{c}{ Farm Categories (No. of Respondents) } \\
\hline & Landless (14) & Marginal (34) & Small (29) & Medium (2) \\
\hline Lack of capital & 57.14 & 38.24 & 31.03 & 0.00 \\
\hline Uncertainty & 0.00 & 0.00 & 10.34 & 0.00 \\
\hline Only verbal contract & 0.00 & 0.00 & 17.24 & 50.00 \\
\hline Higher rent & 21.43 & 35.29 & 24.14 & 0.00 \\
\hline Severe competition & 21.43 & 20.59 & 0.00 & 0.00 \\
\hline Not mentioned & 0.00 & 5.88 & 17.24 & 50.00 \\
\hline Total & 100.00 & 100.00 & 100.00 & 100.00 \\
\hline
\end{tabular}

Result clearly shows that majority of landless and marginal farmers faced capital shortage and its related problem as they are economically vulnerable section of the society. Obviously, tenancy market was competitive as there were large number of land poor farmers against limited quantity of available cultivable land. Few small farmers also faced problem of capital shortage. Medium farmers did not find any problems in tenancy except informal contract between two parties.

\section{Conclusion}

Agricultural farm structure in Bangladesh is characterized by small size of land holding, uneven land distribution and abundance of landless and marginal farmers. Besides these drawbacks, land tenancy practices have given an opportunity to the landless and marginal farmers for acquiring cultivable land to some extent.
Tenancy acted as an equalizer to mitigate land distribution problems. Tenancy market is harshly competitive. Majority of the land poor farmers find difficulties to acquire land due to lack of capital. This problem can be addressed through easy access of government loan. Moreover, few non-government organizations have already initiated easy loan for tenant farmers.

\section{References}

Griffin, K., Khan, A.R. and Ickowitz, A. 2002. Poverty and the distribution of land. $J$. Agrarian Change. 2(3): 279-330.

https://doi.org/10.1111/1471-0366.00036

Haque, Z. and Jinan, T. 2017. Impact of land tenure system on socio-economic characteristics in selected areas of Mymensingh. J. Env. Sci. Nat. Res. 10(2): 133-142.

https://doi.org/10.3329/jesnr.v10i2.39026 
Islam, M.A. and Maharjan, K.L. 2015. Farmers land tenure arrangements and technical efficiency of growing crop in some selected upazilas in Bangladesh. Bangladesh $J$. Agril. Res. 40(3): 347-361. https://doi.org/10.3329/bjar.v40i3.25410

Kabir, M.S., Seamoon, F.R. and Rahman, M.A. 2014. Poverty trend among the lower-class households in a rural area of Bangladesh. $J$. Bangladesh Agril. Univ. 12(2): 337-344. https://doi.org/10.3329/jbau.v12i2.28693

Nasrin, M. and Uddin, M.T. 2011. Land tenure system and agricultural productivity in a selected area of Bangladesh. Progress. Agric. 22(1\&2): 181-192. https://doi.org/10.3329/pa.v22i1-2.16479

Rahman, M.H. and Manprasert, S. 2006. Landlessness and its impact on economic development: A case study on Bangladesh. $J$. Soc. Sci. 2(2): 54-60. https://doi.org/10.3844/jssp.2006.54.60

Raihan, S., Sohani, F. and Ifthekharul, H. 2009. Access to land and other natural resources by the rural poor: The case of Bangladesh.
South Asian Network on Economic Modeling (SANEM), Department of Economics, University of Dhaka, Bangladesh. p. 1. https://mpra.ub.unimuenchen.de/38621/

Rana, S., Faruk, O., Begum, N. and Tabassum, M. 2019. Trend analysis of land utilization in Bangladesh. Int. J. Eng. Tech. Manage. Res. 6(2): 39-46.

https://doi.org/10.29121/ijetmr.v6.i2.2019.354

Rashid, M.M. 2015. BRAC Tenant Farmer Development Project in Bangladesh. pp. 1-6. In: Presentation at the Public-Private Dialogue 2015 Workshop. Copenhagen.

Sen, B. 2018. The Rise of Landless Tenancy in Rural Bangladesh: Analysis of the Recent Evidence. pp. 1-27. In: Presentation made at the BIDS Research Almanac. Dhaka.

Taslim, M.A. and Ahmed, F.U. 1992. An analysis of land leasing in Bangladesh agriculture. Econ. Dev. Cultural Change. 3: 615-628. https://doi.org/10.1086/451963 